\title{
Aspects of Heart Failure in Patients with Ischemic Heart Disease after Percutaneous Coronary Revascularization with Polymer-coated Drug-Eluting Stents versus Bare-Metal Stents
}

\begin{abstract}
MARIANA TUDORAN, CRISTINA TUDORAN*, TUDOR CIOCARLIE, GHEORGHE NICUSOR POP, MARCEL MIHAI BERCEANU-VADUVA, DANA EMILIA VELIMIROVICI*, ABU AWWAD AHMED, DELIA MIRA BERCEANU-VADUVA University of Medicine and Pharmacy Victor Babes, 2 Efimie Murgu Sq., 300041, Timisoara, Romania

Percutaneous coronary revascularization (PCR) with polymer-coated drug-eluting stents (DES) or baremetal stents (BMS) is considered the standard therapy in advanced ischemic heart disease (IHD). Despite revascularisation, many of these patients subsequently develop heart failure with reduced ejection fraction (HFrEF). We analysed 51 patients with IHD, treated by PCR and insertion of DES and/or BMS who later developed HFrEF. Patients with DES where more likely women, of younger age and a higher incidence of diabetes mellitus compared to patients with BMS who were generally men, of older age and had more frequently acute ST-elevation myocardial infarction (STEMI) as indication for PCR. Although patients with $D E S$ had more severe IHD, theirEF was higher, possibly due to the benefits offered by the DES.
\end{abstract}

Keywords: ischemic heart disease, polymer-coated drug-eluting stent, bare-metal stent, heart failure with reduced ejection fraction

Ischaemic heart disease (IHD) represents the most common cause of death and of HFrEF in the developed world [1]. The most effective treatment consists in a successful revascularization of the affected myocardium, realised either by PCR with insertion of stents, or by coronary artery by-pass graft (CABG) [2].

Heart failure secondary to IHD presents an increasing incidence because of the improved survival, attributed to the success of revascularisation by primary PCR in acute myocardial infarctions, but resulting often in left ventricular (LV) remodelling and chronic myocardial dysfunction. The best medical treatment of these patients represents a debated topic in the medical literature [3]. Despite best medical therapy of HFrEF according to guidelines [3], many patients remain symptomatic, with increased morbidity and mortality raising the issue of a new revascularization strategy. Currently, CABG is recommended over PCR for younger patients, with multivessel IHD and severely reduced LV function [1]. This procedure is associated with an increased perioperative risk. PCR involves a much lower risk and the development of more performant DES, treated with immunosuppressive and antiproliferative drugs, with an advanced polymer coating, could improve the evolution of these patients [4].

The aim of this study is to evidence with factors are associated with the presence of HFrEF in patients with IHD treated by PCR and insertion of at least one stent and if there are differences between patients with DES versus those with BMS.

\section{Experimental part}

$D E S$ versus $B M S$

DES are considered superior to BMS for the treatment of IHD, most statistical analyses indicating lower rates of major adverse cardiac events [5, 6]. BMS consist only of a metal structure. DES consist of three parts - the stent platform, the polymer coating that binds the drug to the stent and releases drug and the drug with immunosuppressive and antiproliferative effects (paclitaxel, sirolimus and everolimus) which inhibits neointimal growth that would cause restenosis [4], (fig. 1).

One to three or more layers of polymer are used for the coating: a base layer for adhesion, a main layer that holds and elutes (releases) the drug into the arterial wall by contact transfer, and sometimes a top coat to slow down the release of the drug and extend its effect. The necessity of polymers on DES platforms is dictated by the need of an adequate amount and optimal release of the antiproliferative drugs for achieving ideal DES performance. Polymers selected to be used as a drug carrier should share following features: be biocompatible; do not interact with the drug; provide a platform for appropriate drug-eluting kinetics; behave biologically inert after the drug has been

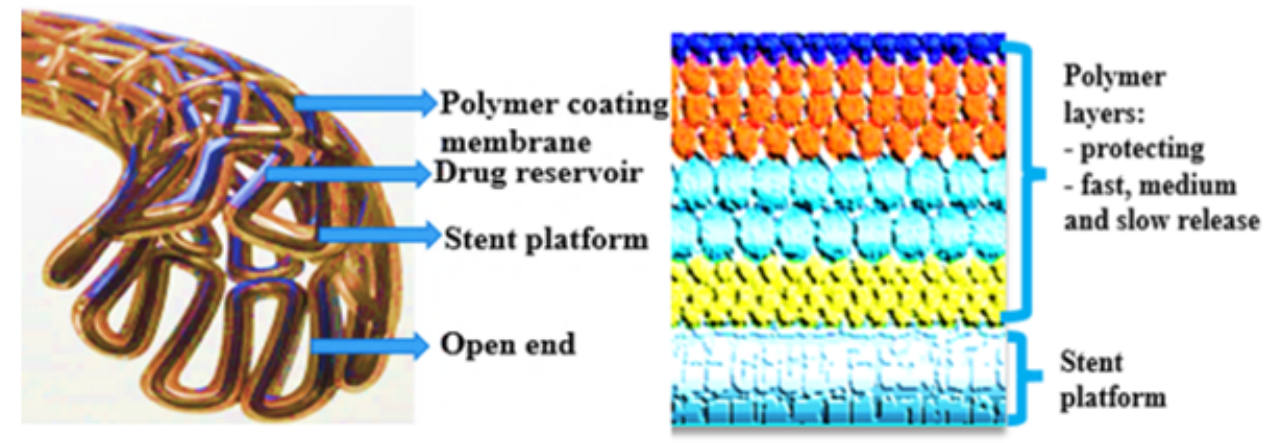

Fig. 1. Structure of a polymercoated drug-eluting stent and of the polymer layers

*email: cristina13.tudoran@gmail.com, Phone: + 40722669086; danavelimirovici@yahoo.com, Phone: 0723211190 
Table 1

POLYMERS USED IN THE STENT COATING

\begin{tabular}{|l|l|l|l|}
\hline \multicolumn{2}{|l|}{ Nonbiodegradable polymers } & Biodegradable polymers \\
\hline Polymer & Proprieties & Polymer & Proprieties \\
\hline Parylene C & $\begin{array}{l}\text { Derivative of poly-paraxylylene, } \\
\text { good barrier properties }\end{array}$ & $\begin{array}{l}\text { Poly (L,D) - } \\
\text { lactic- acid }\end{array}$ & $\begin{array}{l}\text { Fully biodegradable, allows } \\
\text { homogeneous dispersion of the drug }\end{array}$ \\
\hline $\begin{array}{l}\text { Poly-buty1 } \\
\text { methacrylate }\end{array}$ & $\begin{array}{l}\text { Biocompatible with slow drug release } \\
\text { kinetics }\end{array}$ & $\begin{array}{l}\text { Poly-lactide- } \\
\text { co-glycolide }\end{array}$ & $\begin{array}{l}\text { Fully biodegradable due to ability of } \\
\text { polymer crystallinity modification }\end{array}$ \\
\hline $\begin{array}{l}\text { Polyethylene- } \\
\text { co-vinyl-acetate }\end{array}$ & Rapid drug-release kinetics & $\begin{array}{l}\text { Poly(lactide- } \\
\text { caprolactone) }\end{array}$ & $\begin{array}{l}\text { Low biodegradability, facilitates } \\
\text { drug diffusion }\end{array}$ \\
\hline
\end{tabular}

completely eluted, and be mechanically stable at longterm in the dynamics of coronary circulation milieu. Various permanent (biostable) and biodegradable polymers have been used on DES platforms with various results which are still in testing in clinical trials [7-11], (table 1).

\section{Patients group}

This study was conducted on 51 patients, aged between 50 and 75 years, mean age $63.74 \pm 6.69$ years, with angiographically confirmed IHD, treated by PCR and implantation of at least one stent. 28 of them were men and 23 women. Subsequently, they developed HFrEF, treated with medication. During J anuary-December 2018, they were either admitted for decompensated heart failure in the Cardiology Clinic or/and followed in the Ambulatory of our hospital.

They were divided in two groups:

-Group A-the DES group: included 18 patients who received at least one DES during any revascularisation procedure, regardless of whether they had received another type of stent at any time;

-Group B-the BMS-group: included all patients with other types of stents except DES.

\section{Cardiologic evaluation}

The diagnostic of HFrEF was based on the presence of symptoms and clinical signs suggestive for heart failure and on the assessment of a reduced ejection fraction (EF) of under $39 \%$ by echocardiography. All echocardiographic examinations were performed with an Acuson Sequoia C 512 echocardiograph by the same echocardiographist in order to avoid inter-observer differences. On the echocardiography, after a regular exam of cardiac morphology and function, we assessed the ejection fraction
(EF) of the LV by using the Simpson method (normal over $55 \%)$.

\section{Statistical methods}

Data analysis was performed using SPSS v.25 (Statistical Package for the Social Sciences, Chicago, IL, USA). Continuous variables were presented as mean and standard deviation (SD) or median and interquartile range $(I Q R)$, and categorical variables were presented as frequency and percentages. The results of the normality test (Shapiro-Wilk) showed a non-Gaussian distribution, reason why we continued to use nonparametric tests. To evaluate the proportion of stenting indication, associated conditions and risk factor in table 1 we used Fisher's exact test. To compare patients' characteristics in Table 2 we used the Mann-Whitney $U$ test. A p value of less than 0.05 was considered to indicate a statistically significant difference.

The study was approved by the Ethics Committee of our hospital and all patients signed a written informed consent.

\section{Results and discussions}

All fifty-five patients included in our study had angiographically confirmed IHD and underwent one or more PCR with implantation of at least one stent. They were divided in two groups according to the type of stent. The main indications for PCR and stenting, associated diseases and risk factors, in both groups are illustrated in table 2 and the results of clinical and echocardiographic evaluations are presented in table 3.

On average, as compared to patients with BMS, patients with DES were younger $(p=0.004)$ and more likely to be women (61.11\%); they also had a higher prevalence of diabetes mellitus $(p<0.001)$, systemic hypertension,

Table 2

PATHOLOGICAL CONDITIONS IN THE STUDY GROUPS

\begin{tabular}{|c|c|c|c|}
\hline $\begin{array}{l}\text { Characteristics of the study } \\
\text { groups }\end{array}$ & $\begin{array}{l}\text { Group A } \\
\text { PCR and DES } 18\end{array}$ & $\begin{array}{l}\text { Group B } \\
\text { PCR and BMS } 33\end{array}$ & p value \\
\hline \multicolumn{4}{|c|}{ Indication for stenting $\%$} \\
\hline Acute STEMI & $5(27.77 \%)$ & $25(75.75 \%)$ & 0.001 \\
\hline Acute non-STEMII & $3(16.66 \%)$ & $1(3.03 \%)$ & $0.120-\mathrm{ns}$ \\
\hline Stable angina & $2(11.11 \%)$ & $1(3.03 \%)$ & $0.282-\mathrm{ns}$ \\
\hline Multivessel disease & $8(44.44 \%)$ & $6(18.18 \%)$ & $0.057-\mathrm{ns}$ \\
\hline \multicolumn{4}{|c|}{ Associated conditions and risk factors $\%$} \\
\hline Diabetes mellitus & $16(88.88 \%)$ & $4(12.12 \%)$ & $<0.001$ \\
\hline Systemic hypertension & $14(77.77 \%)$ & $24(72.72 \%)$ & $0.750-\mathrm{ns}$ \\
\hline CKD & $8(44.44 \%)$ & $12(36.36 \%)$ & $0.394-\mathrm{ns}$ \\
\hline Male gender & $7(38.88 \%)$ & $21(63.63 \%)$ & $0.080-\mathrm{ns}$ \\
\hline Smoking & $11(61.11 \%)$ & $26(78.78 \%)$ & $0.153-\mathrm{ns}$ \\
\hline Hypercholesterolemia & $12(66.66 \%)$ & $11(33.33 \%)$ & 0.038 \\
\hline Alcohol & $5(27.77 \%)$ & $10(30.3 \%)$ & $0.850-\mathrm{ns}$ \\
\hline
\end{tabular}

Legend: PCR - percutaneous coronary artery revascularisation; DES - drug eluting stent; BMS - bare-metal stent; STEMI - STelevation myocardial infarction; CKD - chronic kidney disease. Fisher's exact test 
Table 3

CLINICAL CHARACTERISTICS OF THE STUDY GROUPS

\begin{tabular}{|l|c|c|c|}
\hline Clinical characteristics & PCR and DES 18 & PCR and BMS 33 & P value \\
\hline Age (years) & $60(55-65)$ & $68(60-70)$ & 0.004 \\
\hline BMI $\left(\mathrm{Kg} / \mathrm{m}^{2}\right)$ & $27(24.75-29.45)$ & $27.5(25-29)$ & $0.906-\mathrm{ns}$ \\
\hline Heart rate (b/min) & $65(60-70)$ & $65(60-70)$ & $0.902-\mathrm{ns}$ \\
\hline Number of stents & $1(1-2)$ & $1(1-1)$ & $0.417-\mathrm{ns}$ \\
\hline Time since last stenting (months) & $12(10-14.25)$ & $19(15.5-21)$ & $<0.001$ \\
\hline Repeated PCR & $5(27.77 \%)$ & $6(18.18 \%)$ & $0.417-\mathrm{ns}$ \\
\hline LVEF (\%) & $27.04(22.81-31.91)$ & $23.72(21.7-25.64)$ & $0.056-\mathrm{ns}$ \\
\hline
\end{tabular}

Legend: PCR -percutaneous coronary artery revascularisation; DES - drug eluting stent; BMS - bare-metal stent;

BMI - body mass index; LVEF-left ventricular ejection fraction. Mann Whitney U test.

hypercholesterolemia $(p=0.038)$ and renal dysfunction. Multivessel disease and stable angina were the main indications for PCR. $27.77 \%$ of patients with DES had repeated PCR, and a higher number of stents, comparing to those with BMS. Patients with BMS were older, were more likely to be men (63.63\%) and more often had primary PCR for acute STEMI as indication for stenting (75.75\%).

All patients included in our study had HFrEF. Those from group $A$, with PCR and DES, had a slightly higher EF, compared to the ones from group $B$, thus the difference was not statistically significant $(p=0.056)$. This aspect could be explained by the fact that in the first group there were younger patients, but, on the other hand, they were more likely to have multivessel disease and diabetes mellitus, both conditions associated with HFrEF.

$88.88 \%$ of our patients with DES were diabetics. In a study regarding outcomes of PCR with stenting in diabetic patients [12] concluded that the consequences of PCR are less favorable in diabetics compared with non-diabetic patients. New angioplasty techniques, such as DES, could improve the results of PCR in diabetic patients.

Other authors debate upon the effectiveness of the new generation of DES on the LV systolic function $[13,14]$ and evidenced an improvement of LVEF after the use of Everolimus-eluting stents. Similar results were reported by Yee et al [15] in patients with severely reduced EF who underwent PCR with DES; however patients undergoing CABG showed greater gains in LVEF $[16,17]$. Other authors debate upon similar results in patients with multivessel disease $[2,15]$.

The prevalence of HFrEF and the outcomes of patients treated with DES versus BMS were analysed in several studies. For example, Lagerqvistin a study realised by using data from the Swedish Coronary Angiography and Angioplasty Registry, analyzed clinical particularities and mortality at 3 years of 6033 patients treated with DES and of 13,738 with BMS and concluded that the mortality was higher in patients with DES [5].

Several meta-analysis provides evidence that revascularization, irrespective of modality, compared with medical therapy, significantly improves survival and other outcomes in patients with $\mathrm{EF} \leq 40 \%$ and significant $\mathrm{CAD}$ $[1,18]$. CABG seems to be a more favorable option [18], although a network meta-analysis of 100 trials with 93 553 patients reported that PCR with new-generation DES resulted in better outcomes compared with initial medical treatment [1].

\section{Conclusions}

Although patients with HFrEF treated by PCR and DES had more severe IHD, with multivessel disease and a higher incidence of diabetes mellitus compared to those with BMS, EF was higher in the first group, possibly due to the benefits offered by the polymer-coated stents.

\section{References}

1. NEUMANN F-J., SOUSA-UVA M., AHLSSON A., ALFONSO F., BANNING A.P., BENEDETTO U. BYRNE R.A., COLLET J.P., FALK V., HEAD S.J., JUNI P., KASTRATI A., KOLLER A., KRISTENSEN S.D., NIEBAUER J., RICHTER D.J., SEFEROVIC P.M., SIBBING D., STEFANINI G.G., WINDECKER S., YADAV R., ZEMBALA M.O. ESC/EACTS Guidelines on myocardial revascularization. European Heart J ournal, 40, nr. 2, 2019, p. 87-165.

2. HANNAN, E.L., WU, C., WALFORD, G., CULLIFORD, A.T., GOLD, J.P., SMITH, C.R. HIGGINS R.S., CARLSON R.E., JONES R.H. Drug-Eluting Stents vs. Coronary-Artery Bypass Grafting in Multivessel Coronary Disease. N Engl J Med, 358, 2008, p. 331-341.

3. PONIKOWSKI, P., VOORS, A.A., ANKER, S.D., BUENO, H., CLELAND, J.G.F., COATS, A.J.S., VOLKMAR Falk, GONZALEZ-JUANATEY J.R., HARJOLA V-P, JANKOWSKA E.A., JESSUP M., LINDE C., NIHOYANNOPOULOS P., PARISSIS J.T., PIESKE B., RILEY J.P., ROSANO G.M.C., RUILOPE L.M., RUSCHITZKA F., RUTTEN F.H., VAN DER Meer P. ESC Guidelines for the diagnosis and treatment of acute and chronic heart failure: The Task Force for the diagnosis and treatment of acute and chronic heart failure of the European Society of Cardiology (ESC). European Heart J ournal, 37, nr. 27, 2016, p. 2129-2200.

4. RIZAS K.D., MEHILLI J. Stent Polymers Do They Make a Difference? Circ Cardiovasc Interv. 2016, 9, nr 6, p. 1-12.

5. LAGERQVIST, B., JAMES, S.K., STENESTRAND, U., LINDBÄCK, J., NILSSON, T., WALLENTIN, L., Long-Term Outcomes with Drug-Eluting Stents versus Bare-Metal Stents in 6. Sweden. N Engl J Med, 356, 2007, p. 1009-1019.

6.STANCU, A., GHISE, A., PENTEA, M., VELIMIROVICI, D.E., PASCA, S., CARPINISAN, L., CRISTINA, R.T., Hematoxylin - eosin- staining in a dog polyarteritys nodosa. Mat. Palst., 54, no. 2, 2017, p. 302-303

7. SHA'AT,F.,PAVALOIU, R.D., DANIELA CRINA SALCEANU, D.C, HLEVCA, C., NECHIFOR, G., Formulation of Polymeric Multicomponent Systems Containing Cardiovascular APIs, Mat. Palst., 55, no. 1, 2018, p. $121-123$

8.MICU, L.M., LAZAR, I., CIRCIUMARU, A., BORDEASU, I., PIRVULESCU, L.D., HLUSCU, M., New Results Regarding Cavitation Behavior of Polymers Modified with Anorganic Substances Coated on Bronze Surfaces, Mat. Plast., 55, no. 3, 2018, p. 460-463

9.BOSINCEANU, D.G., SANDU, I.G., BOSINCEANU, D.N., MARTU, I., SURLARI, Z., FORNA, N.C., Clinical se of a new polymer in complete dentures fabrication I, Mat. Palst., 55 , no. 3, 2018, p. 423-425

10. LAZAR, I., BORDEASU, I., CIRCIUMARU, A., MITELEA, I., BOCII, L.S., BEHAVIOR OF Polymer thin films deposed on bronze surfaces at cavitation erosion, Rev. Chim. (Bucharest), 69, no.10, 2018, p. 2921-2927

11.GRIGORE, N., PIRVUT, V., MIHAI, I., CERNUSCA MITARIU, S.I., MIHAI SAVA, M., HASEGAN, A., Polymer ligating clips in urologic laparoscopic surgery, Mat. Plast., 54 , no. 2, 2017, p. 295-297

12. NABATI, M., TAGHAVI, M., SAFFAR, N., YAZDANI, J., BAGHERIA, B. Alterations in echocardiographic left ventricular function after percutaneous coronary stenting in diabetic patients with isolated severe proximal left anterior descending artery stenosis. Indian Heart J., 69, nr. 2, 2017, p. 146-150. 
13. PARSAEE M.S., NABATI M., SAFFAR, N., TAGHAVI, M., Effects of Everolimus-Eluting Stents on the Left Ventricular Systolic and Diastolic Functions. J Tehran Heart Cent., 10, nr.2, 2015, p. 93-97.

14. TUDORAN, M., TUDORAN, C., High-risk pulmonary embolism in a patient with acute dissecting aortic aneurysm. Niger J Clin Pract, 19, nr. 6, 2016, p. 831-833.

15. YEE N.P., SIU A.M., MPH, DAVIS J ., KAO J . Recovery of Left Ventricular Function After Percutaneous Coronary Intervention Compared to Coronary Artery Bypass Grafting in Patients with Multi-Vessel Coronary Disease and Left Ventricular Dysfunction. Hawaii J Med Public Health. 75, nr. 9, 2016, p. 273-277.

16. COHEN D.J ., OSNABRUGGE R.L., MAGNUSON E.A., WANG K., LI H., CHINNAKONDEPALLI K., PINTO D., ABDALLAH M.S., VILAIN K.A., MORICE M.C., DAW KINS K.D., KAPPETEIN A.P., MOHR F.W., SERRUYS P.W.. Cost-effectiveness of percutaneous coronary intervention with drug-eluting stents versus bypass surgery for patients with 3-vessel or left main coronary artery disease: final results from the Synergy Between Percutaneous Coronary Intervention with TAXUS and Cardiac Surgery (SYNTAX) trial. Circulation. 130, nr. 14, 2014, p. 1146-1157.
17. TUDORAN, C., TUDORAN, M., VLAD, M., BALAS, M., POP, G.N., PARV, F., Echocardiographic evolution of pulmonary hypertension in female patients with hyperthyroidism. Anatol J Cardiol, 20, nr. 3, 2018, p. 174-181.

18. WOLFF G., DIMITROULIS D., ANDREOTTI F., KOfODZIEJ CZAK M., OCCHIPINTI M., CASTIGLIONI B., CALVERI G., MAISANO F., CICCONE M.M., DE SERVI S., NAVARESE E.P. Survival Benefits of Invasive Versus Conservative Strategies in Heart Failure in Patients with Reduced Ejection Fraction and Coronary Artery Disease A Meta-Analysi. Circ Heart Fail., 2017., 10, nr. 1, 2017, p. 1-11.

Manuscript received: 16.12 .2018 